\title{
Ethological parameters and performance of Hy Line W-98 and ISA Brown hens when housed in furnished cages
}

[Parâmetros etológicos e desempenho de poedeiras Hy line W-98 e Isa Brown alojadas em gaiolas enriquecidas]

\author{
V.F.B. Roll $^{1,3}$, G.A.M. Levrino ${ }^{2}$, R.C. Briz ${ }^{2}$, T. Buil ${ }^{2}$ \\ ${ }^{1}$ Faculdade de Agronomia Eliseu Maciel - UFPel \\ Caixa Postal 354 \\ 96010-900 - Pelotas, RS \\ ${ }^{2}$ Facultad de Medicina Veterinaria - Universidad de Zaragoza - Espanha \\ ${ }^{3}$ Bolsista do $\mathrm{CNPq}$
}

\begin{abstract}
This study was carried out throughout a laying period to compare the behaviour and performance of two groups of commercial layers, 180 ISA Brown and 120 Hy line W98, housed at 17 weeks of age in furnished cages with a nest box, perches, dust-bath, and claw shortening device. Based on productive parameters, the model of furnished cages studied is suitable for both, Isa Brown and Hy line hens. The study suggested that strain has a significant effect on feather condition and on some behavioural displays, particularly those related to the use of a dust-bath.
\end{abstract}

Keywords: hen, behaviour, dust-bath, feather cover, furnished cage

\section{RESUMO}

Durante um ciclo completo de postura foram avaliados o comportamento e o desempenho de duas linhagens de poedeiras comerciais, 180 ISA Brown e 120 Hy line W98, alojadas com 17 semanas de idade em gaiolas enriquecidas com ninho, poleiros, banho de areia e dispositivos de desgaste de unhas. Em ambas as linhagens, Isa Brown e Hy line W98, o modelo de gaiola estudado foi apropriado em termos de desempenho produtivo. $O$ estudo sugeriu que a linhagem teve efeito significativo sobre a condição da plumagem e sobre alguns aspectos comportamentais, particularmente, aqueles relacionados ao uso do banho de areia.

Palavras-chave: galinha, comportamento, banho de areia, plumagem, gaiola enriquecida

\section{INTRODUCTION}

In Europe, Directive 1999/74/EC for the protection of laying hens, establishes that since 2012 all layers kept for egg production must be housed in furnished cages. Such cages must be equipped with a nest to allow nesting behaviour (Smith et al., 1993); an area with litter to scratch and peck (Vestergaard et al., 1997); perches to perform their perching behaviour, which also increase bone strength (Abrahamsson and Tauson, 1993); and claw shortening devices to reduce claw length and breaks (Van Niekerk and Reuvekamp, 2000).

Recebido em 15 de fevereiro de 2007

Aceito em 11 de janeiro de 2008

E-mail: roll98@ufpel.edu.br
Currently, the layers breeding programs are mainly focused to increase egg production traits. This selection criterion seems to increase social competition and aggression among hens, characteristics that could be masked in a conventional (unfurnished) cage system with small size group (Hunton, 2002). Laying hens housed in new furnished cage models (with more space and different enrichment components) can show behavioural and production problems. Therefore, it is necessary to know how different of hens cope with furnished cage systems.

The aim of this study was to compare ethological parameters and productive performances of two commercial lines of laying hens housed in furnished cages. 


\section{MATERIAL AND METHODS}

Three hundred hens were used in this experiment, 180 ISA Brown (medium hybrid) and 120 Hy-line W-98 (Leghorn-type). They were housed at 17 -week-old in furnished cages ${ }^{1}$
(Fig. 1). Each cage with 10 hens, was considered as a reply. Dust-bath was opened from one p.m. to three p.m., and filled every two days using sawdust as substrate. A study on the use of space by hens began at 21-week-old and was continued until the end of the experiment (78-week-old).

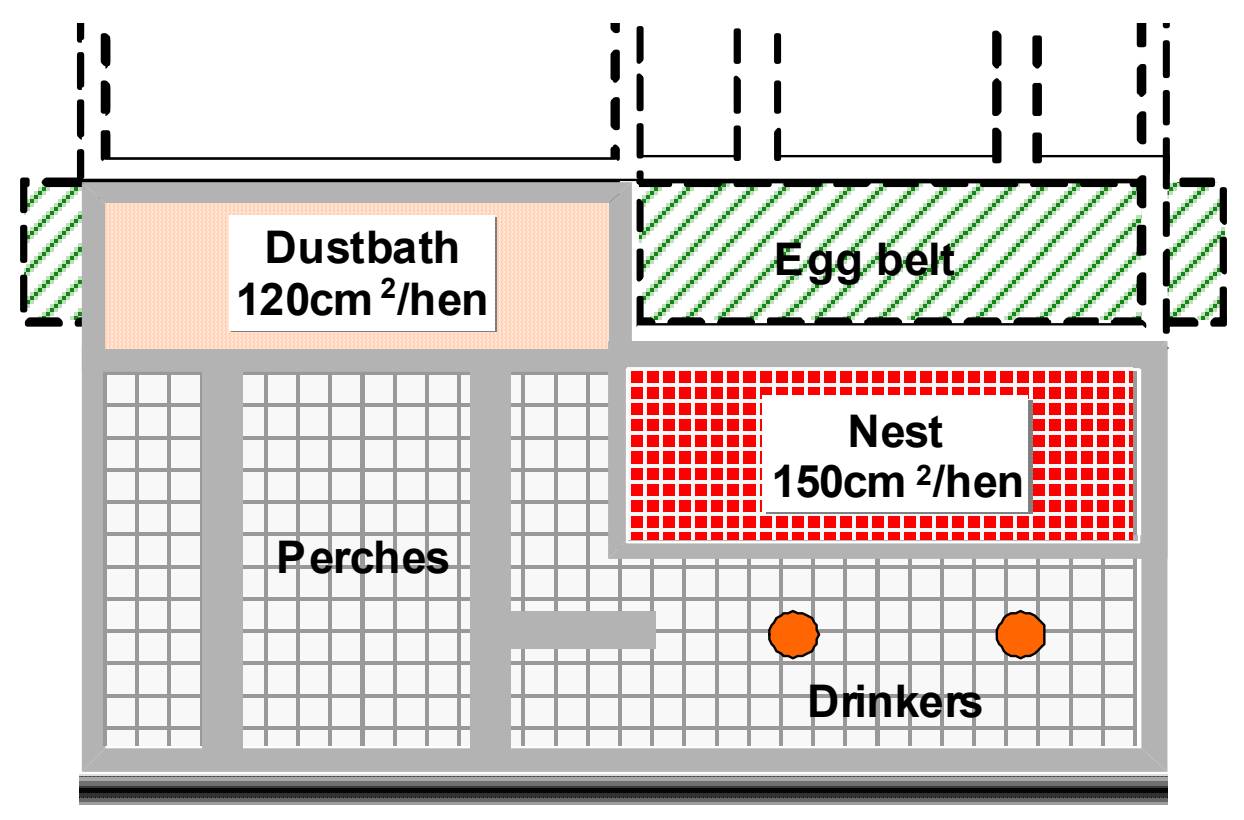

Feed trough

Figure 1. Schematic representation of the furnished cages used in the experiment (stocking density $=750$ $\mathrm{cm}^{2}$ per bird).

Data collection was daily performed and several times a day in order to evaluate the preference of hens to use different areas of the cage - nest, dust-bath, perches, and nipples. The use of dustbath was evaluated by continuous records during the whole open period at 21,26 , and 40 -weekold, using three main criteria: number of hens in the bath; number of hens dust-bathing; and their activity level, from 1 (lowest value), to 3 (highest value) which were recorded by direct visual observation using a focal sampling technique (Lehner, 2003).

During three consecutive days at the $50^{\text {th }}$ and $54^{\text {th }}$ weeks the number of hens performing different activities (eating, drinking, pecking, perching, walking, watching, foraging, grooming, dustbathing, flapping, stretching, lying, nesting, sleeping, and standing) was recorded from four p.m. to seven p.m., in every cage, in 30 seconds intervals. Tonic immobility reaction and its duration were evaluated by number of attempts to achieve immobility, with a maximum of three and 20 minutes, respectively.

Feather cover was analyzed by a score range (Tauson et al., 1984) using a sample of $10 \%$ of the hens at the $19^{\text {th }}, 35^{\text {th }}, 49^{\text {th }}, 62^{\text {nd }}$ and $78^{\text {th }}$ weeks of age. Mortality, egg production, and egg weight were daily recorded from the $17^{\text {th }}$ to $78^{\text {th }}$ weeks in each experimental group.

A fixed effects model was used to analyze the recorded variables:

$\mathrm{Y}_{\mathrm{ik}}=\mu+\mathrm{A}_{\mathrm{i}}+\mathrm{e}_{\mathrm{ik}}$, in which:

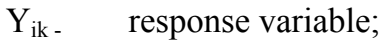

$\mu$ - general mean;

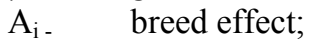

$\mathrm{e}_{\mathrm{ik} \text { - }}$ random error.

${ }^{1}$ Aviplus Big Dutchmann - Vechta, Germany. 
The effects of age and period of the day were added to the statistical model. Data were analyzed using the GLM procedure of SPSS 11.0 for Windows. All differences between means were compared using the Student's t test.

\section{RESULTS AND DISCUSSION}

Table 1 shows the use of space in Isa Brown and Hy Line W-98 during the three periods of the day. The use of nipples area and perches was similar during the morning and the evening. The use of perching area was significantly higher by night, and nesting area was more frequently used in the morning. There were significant differences between breeds in the use of perches and dust-bath, which were more frequently used by the Isa Brown hens. Nest and nipples areas were more used by the Hy Line birds at throughout of the day. Abrahamsson et al. (1996) suggested that the strain of hens could affect the use of the nest area.

Table 1. The use of space in furnished cages by hybrids during morning, evening, and night periods (least square means* $\pm \mathrm{SD})$

\begin{tabular}{lcccc}
\hline \multirow{2}{*}{ Area } & Breed & morning & Day period & night \\
\cline { 3 - 5 } Perches area & ISA Brown & $5.13 \pm 0.03 \mathrm{aA}$ & $4.97 \pm 0.05 \mathrm{aA}$ & $8.31 \pm 0.12 \mathrm{aB}$ \\
& Hy Line W98 & $4.86 \pm 0.03 \mathrm{bA}$ & $4.8 \pm 0.04 \mathrm{bA}$ & $7.71 \pm 0.14 \mathrm{bB}$ \\
\hline Nipples area & ISA Brown & $4.03 \pm 0.03 \mathrm{aA}$ & $4.22 \pm 0.04 \mathrm{aB}$ & $1.46 \pm 0.11 \mathrm{aC}$ \\
& Hy Line W98 & $4.08 \pm 0.03 \mathrm{aA}$ & $4.61 \pm 0.04 \mathrm{bB}$ & $1.99 \pm 0.15 \mathrm{bC}$ \\
\hline Nest area & ISA Brown & $0.84 \pm 0.02 \mathrm{aA}$ & $0.25 \pm 0.02 \mathrm{aB}$ & $0.24 \pm 0.04 \mathrm{aB}$ \\
& Hy Line W98 & $1.06 \pm 0.03 \mathrm{bA}$ & $0.33 \pm 0.02 \mathrm{bB}$ & $0.3 \pm 0.05 \mathrm{aB}$ \\
\hline Dust-bath area & ISA Brown & - & $0.56 \pm 0.04 \mathrm{a}$ & - \\
& Hy Line W98 & - & $0.26 \pm 0.02 \mathrm{~b}$ & - \\
\hline
\end{tabular}

Means within rows followed by distinct capital letters differ $(\mathrm{P}<0.05)$. Means within columns for each parameter followed by distinct lower letters differ $(\mathrm{P}<0.05)$.

*Average number of hens (maximum 10) using each area within the cage at the evaluation moment.

At the $21^{\text {th }}$ week of age, the Hy Line hens were more frequently seen in the dust-bath $(\mathrm{P}<0.05)$ than the Isa Brown birds (Table 2). However, they were mainly exploring this area as less dust-bathing behaviour and less activity level were recorded in such hens. Lindberg and Nicol (1997) reported that only $8.5 \%$ of the times when a hen comes into the dust-bath box is really to perform the dust-bathing behaviour, suggesting that hens use it for other behavioural patterns, as foraging. There were not significant differences at the $26^{\text {th }}$ week of age in the number of hens in the dust-bath, which showed that Hy Line hens progressively loose their interest for this resource, while Isa Brown hens increased their motivation for dust-bathing. At the $40^{\text {th }}$ week of age, a double number of hens was observed in the dust-bath when comparing Isa to Hy-Line, and showing a three-fold value for activity level when dust-bathing $(\mathrm{P}<0.05)$. This shows a higher tendency of this hybrid to perform the dust-bathing behaviour, at least during the evaluated period (i.e. from one p.m. to three p.m.).

Significant differences in the frequency of some behaviours were observed when comparing Isa to Hy-Line birds: sham dust-bathing (0 vs. $2.2 \pm 0.7$, $\mathrm{P}<0.001)$, foraging $(6.5 \pm 0.9$ vs. $9.4 \pm 1.3, \mathrm{P} 0.06)$, watching $\quad(14.5 \pm 1.2$ vs. $10.6 \pm 1.5, \quad \mathrm{P}<0.05)$, standing $(0.8 \pm 0.3$ vs. $2.2 \pm 0.6, \quad \mathrm{P}<0.05)$, and sleeping $(2.0 \pm 0.5$ vs. $0, \mathrm{P}<0.05)$. For Hy Line hens, the time performing sham dust-bathing was $2.2 \%$ of the total patterns observed; while for ISA Brown, this behaviour was not observed. These Hy line hens showed less interest for the dust-bath box.

Lindberg and Nicol (1997) stated that hens try to satisfy their need for dust-bathing in some way; and maybe sham dust-bathing could be a substitute to dust-bathing. Motivation for this behaviour varies in accordance with circadian rhythm, mostly being performed at midday (Vestergaard, 1982). However, according to these results, Hy Line hens mainly showed the sham dust-bathing activity at the end of the evening, when the dust-bath box was closed. This could mean that different hybrids could need different periods and/or duration of dustbathing. Apart from this, the most important differences were related to watching and sleeping behaviour, which were higher for Isa Brown than Hy Line, while foraging and standing were more frequently observed in Hy Line layers. 
Table 2. Least square means and standard deviation of hens present in the dust-bath (hens in the dust-bath area at the moment of observation and hens performing dust-bathing), and the intensity of dust-bathing (activity level)

\begin{tabular}{lccc}
\hline behaviour & Age & Isa Brown & Hy line W98 \\
\hline Number of hens in dust-bath & 21 & $0.54 \pm 0.04 \mathrm{aA}$ & $1.17 \pm 0.05 \mathrm{bA}$ \\
& 26 & $1.57 \pm 0.05 \mathrm{aB}$ & $0.88 \pm 0.07 \mathrm{bB}$ \\
& 40 & $2.01 \pm 0.05 \mathrm{aC}$ & $1.02 \pm 0.06 \mathrm{bAB}$ \\
\hline Number of hens dust-bathing & 21 & $0.35 \pm 0.07 \mathrm{aA}$ & $0.15 \pm 0.04 \mathrm{bA}$ \\
& 26 & $0.92 \pm 0.08 \mathrm{aB}$ & $0.19 \pm 0.06 \mathrm{bA}$ \\
& 40 & $1.84 \pm 0.08 \mathrm{aC}$ & $0.38 \pm 0.05 \mathrm{bB}$ \\
\hline Activity level* & 21 & $0.38 \pm 0.05 \mathrm{aA}$ & $0.22 \pm 0.06 \mathrm{bA}$ \\
& 26 & $1.21 \pm 0.06 \mathrm{aB}$ & $0.25 \pm 0.08 \mathrm{bA}$ \\
\hline
\end{tabular}

Means within rows followed by distinct letters differ $(\mathrm{P}<0.05)$.

Means within columns for each parameter followed by distinct capital letters differ $(\mathrm{P}<0.05)$.

*Assessed by score from 1 (very low intensity) to 3 (very high intensity).

Tonic immobility is a common method used to measure fear state in hens (Jones, 1986), and is also a motor inhibitory state with a decrease in responses to external stimuli. Higher times of immobility show higher fear levels in hens. Significant differences between hybrids were observed in this study. Hy Line hens remained immobile a much longer time than Isa brown $(365 \pm 42$ vs. $109 \pm 12$ seconds, $\mathrm{P}<0.001)$. Number of attempts required to induce the state of immobility for Hy Line hens was lower than for Isa Brown layers $(1.3 \pm 0.1$ vs. $1.99 \pm 0.1$, $\mathrm{P}<0.001)$, which indicates a higher fear state. According to Jones (1996), hens with the highest fear levels cope worst with their environment and can present lower productive performance. But according to these results, fear level of $\mathrm{Hy}$ Line hens was not high enough to affect productivity. Literature suggests that fear reactions in commercial hens breeds can significantly vary (Jones, 1996; Hocking et al., 2001).

Figure 2 represents the evolution of hens feather cover during the whole laying period. Hy Line hens presented a worse feather cover than Isa Brown; this could be due to their longer claw length (Fig. 3). It was found a negative correlation between claw length and total feather cover score $(-0.58, \mathrm{P}<0.01)$ and a low but significant correlation between claw length and feather score on the back $(-0.37, \mathrm{P}<0.05)$. Also, sham dust-bathing could have an effect on worse breast feather cover, as hens brush against the wire mesh.
Table 3 displays the main production parameters in both hybrids throughout their whole laying cycle. The onset of lay began at 19-week-old in the light breed and at 21-week-old in the Isa Brown hens. Thus, the Hy-Line group had an initial advantage because these layers began to lay earlier than Isa Brown hens. This, in part, explains why the number of eggs produced by housed or present hen is higher $(+8$ and +14 eggs, respectively). However, average egg weight, daily egg mass, and $\mathrm{kg}$ of eggs produced by Hy-Line hens from 19 to 78-week-old were $3.7,2.8$, and $800 \mathrm{~g}$ lower, respectively, than those for Isa Brown group. Other experiments performed in the same context also showed different performances between hybrids (Tauson, 1998; Cepero et al., 2000). On the other hand, layers mortality remained under normal figures obtained in commercial production ( $5 \%$ for HyLine and $3.9 \%$ for Isa Brown). Taking into account all these performances, even much better than the production objectives published by both breeding firms, it seems that no problem appeared in adaptation of hens to the studied cage model.

The model of furnished cages studied is suitable for both, Isa Brown and Hy line hens, based on productive parameters. The study revealed that strain has a significant effect on feather condition and on some behavioural displays, particularly those related to the use of a dust-bath. 


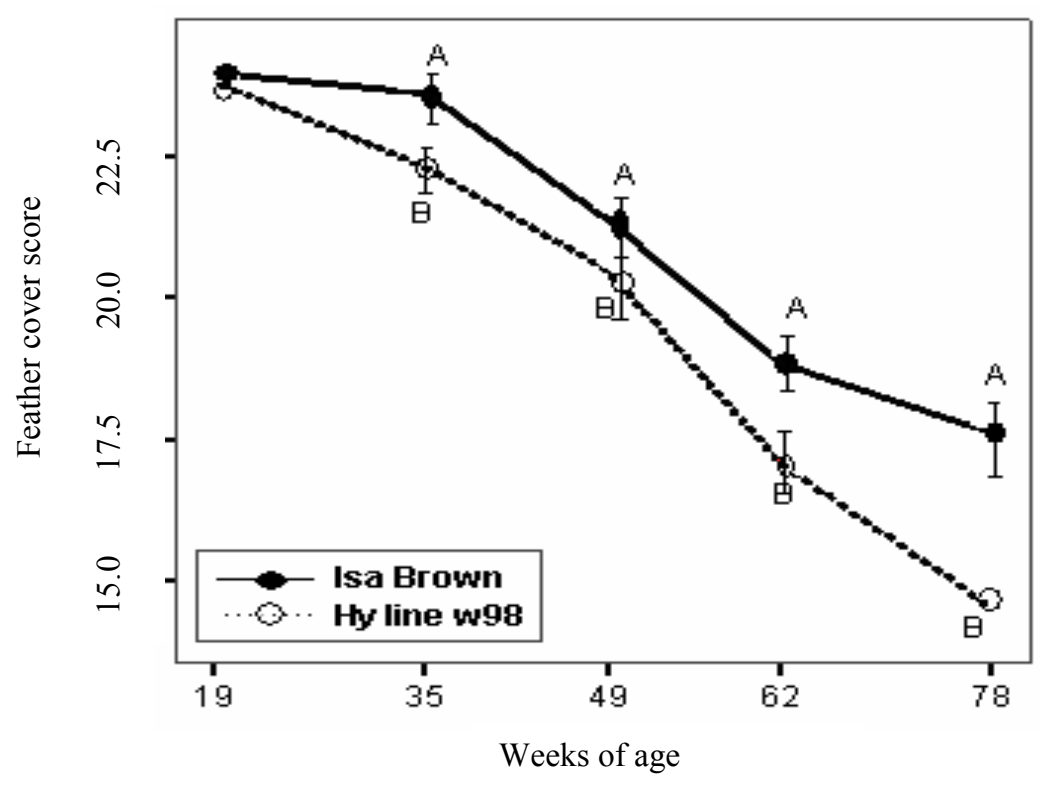

Figure 2. Effect of hybrid on feather cover score ( $19^{\text {th }}$ to $78^{\text {th }}$ weeks of age).

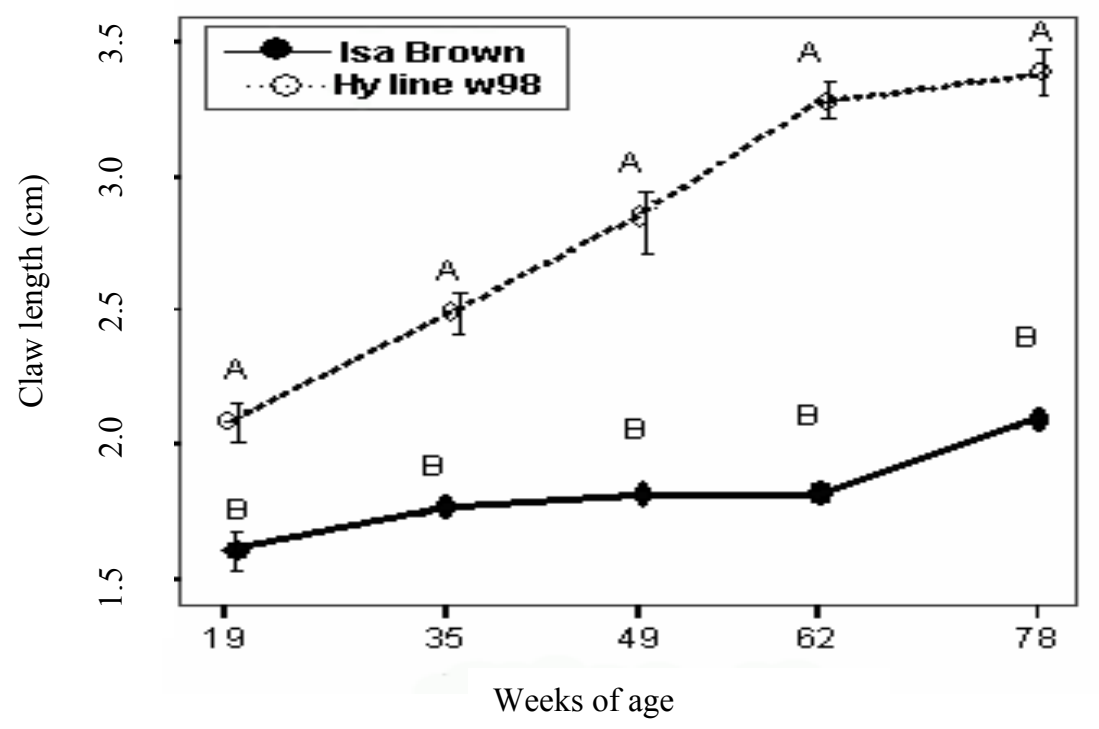

Figure 3. Effect of hybrid on the evolution of claw length $\left(19^{\text {th }}\right.$ to $78^{\text {th }}$ weeks of age $)$.

Table 3. Production traits of hens housed in furnished cages (19 to 78-week-old)

\begin{tabular}{lccc}
\hline & Hy Line W98 & ISA Brown & Significance \\
\hline Egg production (\% hen housed) & 82.98 & 82.56 & $\mathrm{NS}$ \\
Egg production (\% hen day) & 87.35 & 85.41 & $\mathrm{NS}$ \\
Average egg weight (g) & 63.00 & 66.76 & $\mathrm{P}=0.01$ \\
Egg mass output (hen housed) & 52.28 & 55.12 & $\mathrm{P}=0.08$ \\
Egg mass output (hen day) & 55.03 & 57.02 & $\mathrm{NS}$ \\
Egg number/hen housed & 348.53 & 340.98 & $\mathrm{NS}$ \\
Egg number/hen day & 366.88 & 352.74 & $\mathrm{NS}$ \\
Eggs/hen housed $(\mathrm{kg})$ & 21.96 & 22.76 & $\mathrm{P}=0.08$ \\
Eggs/hen day $(\mathrm{kg})$ & 23.11 & 23.55 & $\mathrm{NS}$ \\
\hline
\end{tabular}




\section{ACKNOWLEDGMENTS}

This research was supported by the Ministerio de Ciencia y Tecnología of Spain (Projects AGF970932 and PETRI PTR 1995 0449-OP) and cosupported by Zucami Poultry Equipment Company, Asociación Española de Produtores de Huevos (INPROVO) and the Ministerio de Agricultura, Pesca y Alimentación de España.

\section{REFERENCES}

ABRAHAMSSON, P.; TAUSON R. Effect of perches at different positions in conventional cages for laying hens of two different strains. Acta Agric. Scand., Sect. A, Anim. Sci., v.43, p.228-235, 1993.

ABRAHAMSSON, P.; TAUSON, R.; APPLEBY, M.C. Behaviour, health and integument of four hybrids of laying hens in modified and conventional cages. Br. Poult. Sci., v.37, p.521-540, 1996.

CEPERO, R.; MARÍA, G.; HERNANDIS, A. Productividad en jaulas enriquecidas: resultados preliminares. SYMPOSIUM WORLD POULTRY SCIENCE ASSOCIATION. 37., 2000, Barcelona. Proceedings... Barcelona, 2000. p.176-184.

HOCKING, P.M.; CHANNING, C.E.; WADDINGTON, D. et al. Age-related changes in fear, sociality and pecking behaviours in two strains of laying hen. Br. Poult. Sci., v.42, p.414423, 2001.

HUNTON, P. Welfare regulations and their effects on breeding and genetics in laying hens. World Poult., v.18, p.20-21, 2002.

JONES, R.B. The tonic immobility reaction of the domestic fowl: a review. World's Poult. Sci. J., v.42, p.82-96, 1986.
JONES, R.B. Fear and adaptability in poultry: insights, implications, and imperatives. World's Poult. Sci. J., v.52, p.131-174, 1996.

LEHNER P.N. (Ed). Handbook of ethological methods. London: Cambridge University, 2003. $672 p$.

LINDBERG, A.C.; NICOL, C.J. Dust-bathing in modified battery cages: Is sham dust-bathing an adequate substitute? Appl. Anim. Beh. Sci., v.55, p.113-128, 1997.

SMITH, S.F.; APPLEBY, M.C.; HUGHES, B.O. Nesting and dust bathing by hens in cages: Matching and mis-matching between behaviour and environment. Br. Poult. Sci., v.34, p.21-33, 1993.

TAUSON, R. Health and production in improved cage designs. Poult. Sci., v.77, p.1820-1827, 1998.

TAUSON, R.; AMBROSEN, T.; ELWINGER, $\mathrm{K}$. Evaluation of procedures for scoring the integument of laying hens - Independent scoring of plumage condition. Acta Agric. Scand., Sec. A, Anim. Sci., v.34, p.400-408, 1984.

VAN NIEKERK, TH.G.C.M.; REUVEKAMP, B.F.J. Abrasive strips for laying hens: how can we get a durable, effective device? World Poultr., v.16. p.16-17, 2000.

VESTERGAARD, K. Dust-bathhing in the domestic fowl - diurnal rhythm and dust deprivation. Appl. Anim. Ethol., v.8. p.487-495, 1982.

VESTERGAARD， K.S.; SKADHAUGE， E.; LAWSON L.G. The stress of not being able to perform dust-bathing in laying hens. Physiol. Behav., v.2, p.413-419, 1997. 